\title{
Observations of enhanced thinning in the upper reaches of Svalbard glaciers
}

\author{
T. D. James ${ }^{1}$, T. Murray ${ }^{1}$, N. E. Barrand ${ }^{2}$, H. J. Sykes ${ }^{1}$, A. J. Fox ${ }^{2}$, and M. A. King ${ }^{3}$ \\ ${ }^{1}$ Department of Geography, Swansea University, Swansea, UK \\ ${ }^{2}$ British Antarctic Survey, Cambridge, UK \\ ${ }^{3}$ School of Civil Engineering and Geosciences, Newcastle University, Newcastle upon Tyne, UK
}

Correspondence to: T. D. James (t.d.james@ swansea.ac.uk)

Received: 5 February 2012 - Published in The Cryosphere Discuss.: 15 March 2012

Revised: 1 November 2012 - Accepted: 2 November 2012 - Published: 20 November 2012

\begin{abstract}
Changes in the volume and extent of land ice of the Svalbard archipelago have been the subject of considerable research since their sensitivity to changes in climate was first noted. However, the measurement of these changes is often necessarily based on point or profile measurements which may not be representative if extrapolated to a whole catchment or region. Combining high-resolution elevation data from contemporary laser-altimetry surveys and archived aerial photography makes it possible to measure historical changes across a glacier's surface without the need for extrapolation. Here we present a high spatial resolution time-series for six Arctic glaciers in the Svalbard archipelago spanning 1961 to 2005. We find high variability in thinning rates between sites with prevalent elevation changes at all sites averaging $-0.59 \pm 0.04 \mathrm{~m} \mathrm{a}^{-1}$ between 1961-2005. Prior to 1990, ice surface elevation was changing at an average rate of $-0.52 \pm 0.09 \mathrm{~m} \mathrm{a}^{-1}$ which decreased to $-0.76 \pm 0.10 \mathrm{~m} \mathrm{a}^{-1}$ after 1990 . Setting the elevation changes against the glaciers' altitude distribution reveals that significant increases in thinning rates are occurring most notably in the glaciers' upper reaches. We find that these changes are coincident with a decrease in winter precipitation at the Longyearbyen meteorological station and could reflect a decrease in albedo or dynamic response to lower accumulation. Further work is required to understand fully the causes of this increase in thinning rates in the glaciers' upper reaches. If on-going and occurring elsewhere in the archipelago, these changes will have a significant effect on the region's future mass balance. Our results highlight the importance of understanding the climatological context of geodetic mass balance
\end{abstract}

measurements and demonstrate the difficulty of using index glaciers to represent regional changes in areas of strong climatological gradients.

\section{Introduction}

The glaciers and ice caps of Svalbard (covering ca. $36000 \mathrm{~km}^{2}$ ) are considered to be an early indicator of Arctic cryospheric response to climate change due to their position at the northern extent of the warm North Atlantic currents and consequent sensitivity to climatic trends (Fleming et al., 1997; Lefauconnier et al., 1999). Thus, there have been a number of important investigations into the mass balance of the archipelago's ice. Early reports of stake and pit records dating back to the 1950s found that several Svalbard glaciers were in negative balance, and the authors hypothesized that this had probably been the case since their Little Ice Age maximum in the early 20th century (Hagen and Liestøl, 1990; Lefauconnier et al., 1999). The consistent negative balance suggested that Svalbard glaciers were not in balance with current climatic conditions. However, the lack of significant trend in the rates of mass loss indicated no response to atmospheric warming. A pan-Arctic study of mass balance also reported high rates of mass loss in Svalbard at three glaciers between 1945 and 1995 ( $-0.55 \mathrm{~m}$ water equivalent (w.e.) $\mathrm{a}^{-1}$ ) but again without any signal of anthropogenic-driven warming suggesting any such signal could be lost in the high annual variability (Dowdeswell et al., 1997). 
The difficulty in generalising volume or mass balance changes to the archipelago from point or profile data is that they do not necessarily account for the ice hypsometric distribution or the strong climatic gradients that prevail in Svalbard (Førland and Hanssen-Bauer, 2003). The importance of these parameters was recognized by Hagen et al. (2003) who applied average net balance/altitude curves derived from direct mass balance measurements, ice cores and ground penetrating radar (GPR) in 13 identified regions around the archipelago. Using data that covered the period 1969 to 1999 , they measured a "slightly negative" net balance $\left(-0.014 \pm 0.003 \mathrm{~m}\right.$ w.e. $\left.\mathrm{a}^{-1}\right)$ with the majority of loss coming from smaller mountain glaciers with higher elevation ice caps closer to balance. Advances in airborne and spaceborne surveying have significantly improved the distribution of mass balance measurements to better capture regional variability. Centreline airborne laser surveys in 1996 and 2002 over 16 ice caps and glaciers revealed a complex pattern of elevation change with mean changes of $-0.19 \mathrm{~m}$ w.e. $\mathrm{a}^{-1}$ (Bamber et al., 2005). A historical context was provided using old topographic maps and aerial photographs which gave estimated mass changes of $-0.30 \mathrm{~m}$ w.e. $\mathrm{a}^{-1}$ from the mid1930s to 1990 in the west and southwest regions (Nuth et al., 2007); an average of $-0.53 \mathrm{~m}$ w.e. $\mathrm{a}^{-1}$ for the ice caps of the island of Edgeøya between 1970-2002 (Kääb, 2008); and $-0.36 \pm 0.02 \mathrm{~m}$ w.e. $\mathrm{a}^{-1}$ between the $1960 \mathrm{~s}$ and early $2000 \mathrm{~s}$ (Nuth et al., 2010).

The mass balance results of the studies cited above vary considerably, and comparison is difficult due to differences in methodology, study area and temporal coverage. However, there is general agreement that the ice of the Svalbard archipelago is significantly losing mass. While reports based on data from the 1990s and earlier found no strong evidence of atmospheric warming, more recent research suggests that rates of mass loss are increasing and that this is likely attributable to local climate trends (Kohler et al., 2007). However, mass balance studies have been hampered by a variety of limitations including short time series, low spatial resolution and/or poor distribution of sample sites. Recent evidence suggests that sparse direct or indirect mass balance data are not necessarily representative of regional-scale or even glacier-wide mass changes (Barrand et al., 2010; Berthier et al., 2010). As yet, no study of Svalbard mass balance has been able to provide the following simultaneously: (i) a widely spread sample of sites; (ii) multiple-decade time series; (iii) over several epochs; and (iv) using high-resolution, full-width topographic data.

In this paper we combine historical aerial photographs and contemporary airborne laser altimetry (lidar) surveys to produce three to four epochs of high-resolution DEMs for six sites around Svalbard. The resulting volume change measurements are produced from tens of thousands of individual change measurements for each site that typically cover the full glacier width without the need for extrapolation. This approach enables the detection of spatially vari- able changes that are not necessarily represented by centreline profiles or low-resolution studies and therefore will provide improved understanding of glacier mass balance in the Svalbard archipelago.

\section{Data and methods}

\subsection{Topographic modelling}

We targeted a number of potential sites around the Svalbard archipelago for topographic modelling. Site selection was based on spatial distribution, elevation range, aspect, and suitability for photogrammetry. Since photogrammetry is dependent on stable surfaces from which ground control points (GCPs) can be measured, potential sites were limited to those whose geometry provided a sufficient distribution of exposed bedrock and stable depositional features. This necessitated the exclusion of the large ice cap on the islands of Nordaustlandet and Kvitøya. Aerial photographic coverage of Svalbard has been frequent but incomplete with only the 1990 campaign offering near complete coverage of the archipelago. Thus, during the site selection process we identified glaciers where at least two epochs of historic photographs were available. However, because of the poor image quality and processing difficulty, we opted to exclude the high-oblique photographs from the 1930s. Since the methods employed here cannot differentiate between climatedriven elevation changes and those from surge and tidewater dynamics over these timescales, we limited sites to landterminating, non-surge-type glaciers. Therefore, the results presented below do not account for any dynamically driven changes in glacier volume. We have also not accounted for any elevation errors due to date-offsets between the photographic epochs since these errors (on the order of a meter) are negligible compared to the large changes expected over such long periods (upwards of $100 \mathrm{~m}$ ).

Of the sites selected, high-resolution lidar surveys were successfully undertaken for 6 glaciers including Austre Brøggerbreen (AB), Albrechtbreen (AL), Grønfjordbreen (GB), Gullfaksebreen (GF), Midtre Lovénbreen (ML) and Slakbreen (SB) (Fig. 1 and Table 1). Surveys were acquired during summer 2003 and 2005 by the Airborne Research and Survey Facility (ARSF) of the UK's Natural Environment Research Council (NERC) using an Optech ALTM 3033 laser scanner that recorded first and last laser return and accompanying 8-bit laser return intensity. Since AL and GF both extend into large ice caps, which are inappropriate for photogrammetry, these catchments could not be surveyed in their entirety. We estimate that our surveys cover $\sim 35 \%$ of the area and $65 \%$ of the elevation range of the AL catchment based on Hagen et al. (1993) estimates. For GF we estimate $\sim 50 \%$ of the area and $93 \%$ of the elevation range. For both glaciers our coverage includes the areas of greatest change 


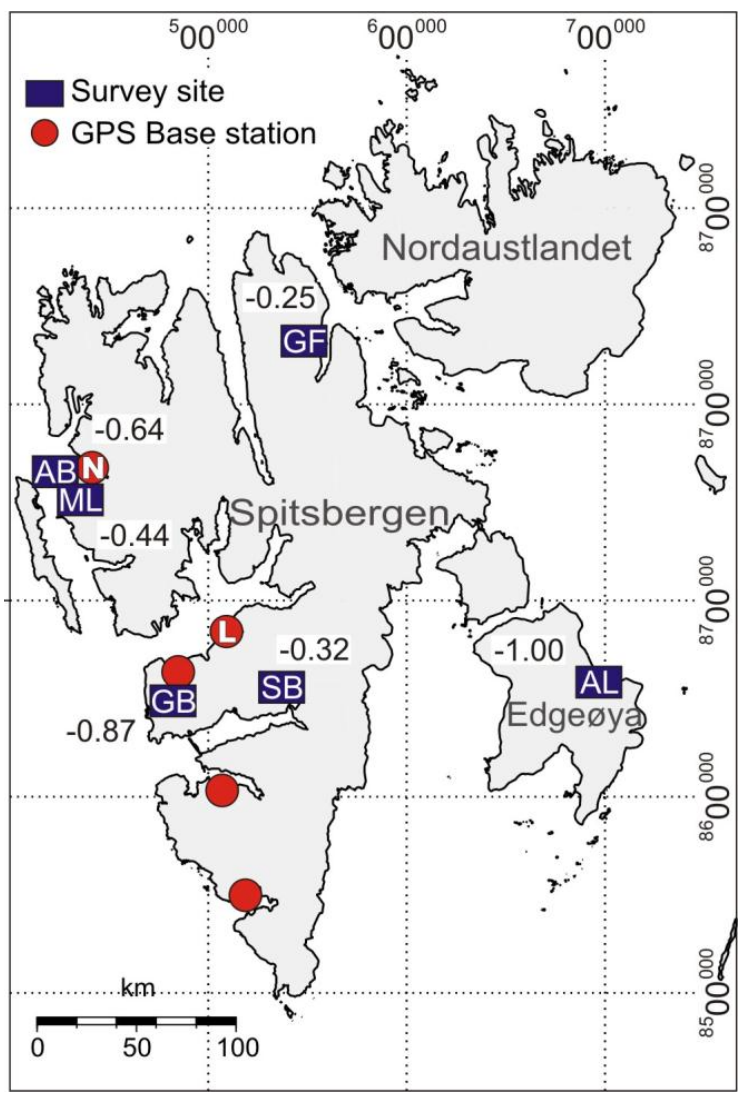

Fig. 1. Sites included in the study are Austre Brøggerbreen (AB); Albrechtbreen (AL); Grønfjordbreen (GB); Gullfaksebreen (GF); Midtre Lovénbreen (ML); and Slakbreen (SB). GPS base station locations are shown by red circles. Numbers for each site are the mean annual elevation change $\overline{\Delta h}$ over the period of observation in $\mathrm{ma}^{-1}$. Logistical support was based at Longyearbyen (L) and $\mathrm{Ny}-$ Ålesund $(\mathrm{N})$. Meteorological data were collected at the Longyearbyen station, which was relocated $\sim 6 \mathrm{~km}$ from the town site to its current airport site in 1975. The icecap island of Kvitøya is off the map located $\sim 100 \mathrm{~km}$ to the east of Nordaustlandet. Map coordinates for this and all subsequent figures are in meters, UTM Zone $33 \mathrm{X}$.

and we turn to previous studies for indications of changes at higher altitudes.

Standard post-processing of lidar data requires coincident, high-quality global positioning system (GPS) data from base stations within $\sim 50 \mathrm{~km}$ of the aircraft, which we installed and operated during the airborne campaigns (Fig. 1). Since two of our sites (AL and GF) were beyond this range, we carried out the aircraft GPS component of post-processing using the processing software, Track, part of the GAMIT/GLOBK package (Chen, 1998; Herring et al., 2010). This allowed us to examine the effects of errors and apply a model to account for the tropospheric zenith delay (TZD) of the GPS signals. We did this by parameterising the TZD for every measurement epoch within Track's Kalman filter. For these data, the analysis produced only negligible improvement in data quality and hence the standard analysis undertaken by the Unit for Landscape Modelling, University of Cambridge, was used for all sites in this study. Resulting point clouds had a density that ranged from 1-3 points per $\mathrm{m}^{2}$.

As an initial quality control, lidar data points with low laser return intensity were checked for errors since lidar elevation quality is highly dependent on signal-to-noise ratio (Wehr and Lohr, 1999) and thus is more likely to represent erroneous elevation measurements. Additionally, it is important to check lidar quality independently, typically against differential GPS (dGPS). Similarly to Joerg et al. (2012), who undertook a comprehensive uncertainty assessment of multi-temporal lidar datasets, lidar data were collected over a reference surface, in this case the local airport runway $(\mathrm{L}$, Fig. 1), whose surface had been surveyed with dGPS. The comparison confirmed that errors were well within the manufacturer's specifications of $\pm 0.10 \mathrm{~m}$. However, this comparison did not account for any errors controlled by surface characteristics like reflectivity, slope and roughness, which required temporally coincident ground truth data. The 2005 lidar data were compared to on-ice dGPS at two sites in NW Svalbard which revealed standard deviations of 0.18 and $0.16 \mathrm{~m}$ at $\mathrm{AB}$ and ML, respectively (Barrand et al., 2010), with negligible systematic error. As these data were collected over a 6-day period around the date of lidar acquisition, they were influenced by the changing elevation of the ice surface. Therefore, for the purposes of this study, we adopt the manufacturer's conservative quoted error of $\pm 0.10 \mathrm{~m}$.

Historical DEMs were generated for all epochs using archived stereo aerial photography held by the Norwegian Polar Institute (Table 1), which were processed in the SOCET SET digital photogrammetry suite. The use of a calibrated metric camera during each historic mission meant that internal camera errors (e.g. lens distortions) could be modelled and removed to improve DEM quality. GCPs were extracted from the contemporary lidar DEMs on stable land surfaces around each site with the aid of image enhancement techniques like relief-shading and contrast stretching. To compensate for the lower quality of lidar-derived GCPs compared to traditional survey-quality ground control, we collected a larger number of GCPs (40 to 80 points) and tie points ( $>100$ points) than would traditionally be used in order to increase the measurement redundancy in the photographic block adjustment. For more detailed information on this approach, see James et al. (2006) and Barrand et al. (2009).

Prior to automated DEM extraction, coarsely spaced DEMs $(\sim 100 \mathrm{~m})$ were measured manually using 3-D visualisation to provide a starting surface or "seed" DEM for automatic DEM extraction. We found this greatly decreased the number of erroneous or unsuccessful correlations in the final DEM, especially in areas of lower image texture. DEMs were then extracted automatically from the adjusted photographs on a $10 \mathrm{~m}$ grid. In areas of low visible contrast (i.e. areas 
Table 1. Acquisition details of airborne laser altimetry (lidar) and photographic surveys.

\begin{tabular}{|c|c|c|c|c|c|}
\hline & \multirow[b]{2}{*}{$\begin{array}{l}\text { Elevation Range } \\
\text { (m a.s.l.) }\end{array}$} & \multicolumn{2}{|c|}{ Lidar } & \multicolumn{2}{|c|}{ Photography } \\
\hline & & Acquisition Date & $\begin{array}{l}\# \text { of Points } \\
\left(\times 10^{6}\right)\end{array}$ & Acquisition Date & Scale \\
\hline Austre Brøggerbreen (AB) & $90-650$ & 06-07-2005 & 31.8 & $\begin{array}{l}28-07-1966 \\
05-08-1977 \\
20,25-08-1990\end{array}$ & $\begin{array}{l}1: 50000 \\
1: 50000 \\
1: 50000\end{array}$ \\
\hline Albrechtbreen (AL) ${ }^{1}$ & $50-300$ & 14-08-2005 & 42.0 & $\begin{array}{l}08-1971^{2} \\
22,27-07-1990\end{array}$ & $\begin{array}{l}1: 30000 \\
1: 50000\end{array}$ \\
\hline Grønfjordbreen (GB) & $35-700$ & 07-07-2005 & 54.4 & $\begin{array}{l}19-08-1969 \\
02-07-1990 \\
\end{array}$ & $\begin{array}{l}1: 50000 \\
1: 50000 \\
\end{array}$ \\
\hline Gullfaksebreen $(\mathrm{GF})^{1}$ & $65-890$ & 09-07-2005 & 98.7 & $\begin{array}{l}07,09-07-1961^{3} \\
30-07-1966 \\
22,28-07-1990\end{array}$ & $\begin{array}{l}1: 45000 \\
1: 50000 \\
1: 50000\end{array}$ \\
\hline Midtre Lovénbreen (ML) & $75-650$ & $\begin{array}{l}09-08-2003 \\
05-07-2005\end{array}$ & 23.5 & $\begin{array}{l}28-07-1966 \\
05-08-1977 \\
20,25-08-1990\end{array}$ & $\begin{array}{l}1: 50000 \\
1: 50000 \\
1: 50000\end{array}$ \\
\hline Slakbreen (SB) & $180-1000$ & 08-08-2003 & 46.3 & $\begin{array}{l}23-25-08-1961 \\
16-08-1977 \\
22-07-1990\end{array}$ & $\begin{array}{l}1: 40000 \\
1: 20000 \\
1: 50000\end{array}$ \\
\hline $\begin{array}{l}1 \text { Photographic and lidar coverage do } \\
\text { method's reliance on the measuremen } \\
\text { photogrammetry. For AL, } 35 \% \text { of t } \\
\text { surveyed. } \\
2 \text { Exact acquisition date unknown. } \\
3 \text { Early epoch coverage was spread ov } \\
\text { thus the } 1961 \text { photographs were merg }\end{array}$ & $\begin{array}{l}\text { ot cover the whole catc } \\
\text { of ground control point } \\
\text { area and } 65 \% \text { of the } \\
\text { two campaigns. Eleva }\end{array}$ & $\begin{array}{l}\text { nt area of these glaciers } \\
\text { stable features and the } \\
\text { tion range were survey } \\
\text { differences over this pe } \\
\text { otographs. }\end{array}$ & $\begin{array}{l}\text { se highest elev: } \\
\text { nce of image te } \\
\text { or GF } \sim 50 \% \text { o } \\
\text { in the area of o }\end{array}$ & $\begin{array}{l}\text { s include featureless ice } \\
\text { area and } 93 \% \text { of the el } \\
\text { p were within the meas }\end{array}$ & $\begin{array}{l}\text { Due to the } \\
\text { for } \\
\text { on range were } \\
\text { ent error and }\end{array}$ \\
\hline
\end{tabular}

of dark shadow or snow cover), DEM points were measured manually where possible at a spacing of $\sim 50 \mathrm{~m}$, using the software's 3-D-editing capabilities. These areas tended to be gently sloped, and thus the coarser resolution was sufficient for accurately representing these surfaces.

Since glacier surfaces are not stable over time, the assessment of glacier DEM quality from historical imagery is not straightforward. Typically, DEM quality is measured in terms of (i) the fit of measured points and camera calibration parameters to the block adjustment solution given in rootmean-square error (RMSE) of GCP X, Y and Z coordinates; and (ii) the comparison of the DEM to an independent check dataset (Wolf and Dewitt, 2000). As temporally coincident validation data were not available for the historical imagery, we assessed the DEM quality by comparing the lidar DEM at three off-ice test sites characterised as topographically stable and with similar textural and relief characteristics to the ice. This was carried out instead of a blanket comparison to all off-ice points since we could not assume that (i) all off-ice areas had remained unchanged over the long period of study (i.e. slope erosion, ice-cored moraines and shifting outwash plains); and (ii) the suitability of the ice- and off-ice surface for photogrammetry was similar in terms of image texture and contrast.
Results of the photogrammetric block adjustment suggested a good fit of the measured parameters to the block solution with average RMSE of the ground control in $\mathrm{X}, \mathrm{Y}$ and $\mathrm{Z}$ of $1.33,1.50$ and $0.43 \mathrm{~m}$, respectively. Comparison to the lidar at the test sites yielded low mean error of $0.21 \mathrm{~m}$ and standard deviation of $\pm 1.55 \mathrm{~m}$. Although we expect the quality of on ice points to be better than this, to compensate for the degree of spatial autocorrelation of elevation errors expected in the differenced DEMs (Rolstad et al., 2009), we conservatively adopted the higher error estimate of $\pm 1.55 \mathrm{~m}$ for the photogrammetric DEM error in the following analysis.

\subsection{Sequential DEM analysis}

Two periods of elevation and volume change were measured across our sample glaciers using sequential DEM analysis approximately covering the periods 1961-1990 and 19902005 (Table 1). These two periods, which were available at all six sites, were the main focus of this study. However, photographs from 1977 were also available at AB, ML and $\mathrm{SB}$ providing an intermediate period over which elevation and volume changes could be measured. The relatively highresolution lidar DEMs were downsampled to the same grid 
as the photogrammetric DEMs, and the surfaces were differenced on a pixel by pixel basis. Volume changes were calculated over the maximum area of ice coverage using pixel summation (e.g. Etzelmüller et al., 1993; Kohler et al., 2007; Barrand et al., 2010).

Differencing DEMs for volume and mass change measurement, known as the geodetic method, is more accurate over long periods than the glaciological method (Cox and March, 2004) where DEM quality is high and errors due to changes in ice density are negligible compared to elevation changes over these time scales. Also, the geodetic method can provide measurement of elevation and volume changes across a glacier's full area where conditions allow. This approach reduces or eliminates the need for extrapolation of point or profile measurements and is ideal in Svalbard where it has been argued that climate-driven elevation changes are large compared to changes in ice flow (Nuth et al., 2007) and ice density (Kohler et al., 2007) over these long time periods.

To put our results in the context of the area-altitude distribution of the archipelago's ice, we compare the hypsometry of the whole archipelago to the hypsometry of our sites. To produce the pan-Svalbard hypsometry, drainage basins were digitized from Hagen et al. (1993) and geocoded to the Norwegian Polar Institute $100 \mathrm{~m}$ Svalbard DEM using map grid intersections. The digitized basins were converted to binary masks and were applied to the DEM to identify on-ice points. Results for the archipelago are provided in $50 \mathrm{~m}$ elevation bands with and without the ice caps of Nordaustlandet and Kvitøya. Hypsometry curves for our sites were produced both as a sum total of all sites and as averages for each site also in $50 \mathrm{~m}$ elevation bands.

\section{Results}

Our sequential DEM analysis reveals changes that are consistent with glaciers adjusting to a warming climate with thinning greatest at the retreating termini and decreasing upglacier (Schwitter and Raymond, 1993) (Fig. 2). Terminus position data in Table 2 show that all six glaciers experienced significant retreat over the period of observation. However, there is high variability in changes of frontal position and elevation attributable to both the strong regional temperature and precipitation gradients as well as local glacier geometry. We discuss this below in the context of the glaciers' iceelevation distribution.

Elevation change statistics (Table 3; provided in ice equivalent units unless otherwise stated) show maximum elevation changes $\left(\Delta h_{\max }\right)$ between $1961-2005$ were recorded at SB and GB, which both lost more than $90 \mathrm{~m}$ of elevation over the study period $\left(\sim 2.3 \mathrm{~m} \mathrm{a}^{-1}\right)$ at their 2003 and 2005 termini, respectively. The northeast site (GF), an area thought to be closer to balance (Bamber et al., 2005; Moholdt et al., 2010; Nuth et al., 2010), experienced elevation losses of almost $50 \mathrm{~m}\left(\sim 1.3 \mathrm{~m} \mathrm{a}^{-1}\right)$. The site with the highest mean annual
Table 2. Site terminus retreat relative to earliest epoch along dotted lines shown in Fig. 2.

\begin{tabular}{ccccc}
\hline & & \multicolumn{3}{c}{ Terminus Retreat $\left(\mathrm{m} \mathrm{a}^{-1}\right)$} \\
\cline { 3 - 5 } & Data Coverage & Whole Period & Pre-1990 & Post-1990 \\
\hline AB & $1966-2005$ & 22 & 25 & 35 \\
AL & $1971-2005$ & 42 & 33 & 64 \\
GB & $1969-2005$ & 30 & 38 & 29 \\
GF & $1966-2005$ & 12 & 11 & 19 \\
ML & $1966-2005$ & 12 & 13 & 10 \\
SB & $1961-2003$ & 32 & 20 & 59 \\
\hline
\end{tabular}

elevation change $(\overline{\overline{\Delta h}})$ was low-lying $\mathrm{AL}$ on the eastern island of Edgeøya, which lost an average of $1.00 \pm 0.03 \mathrm{~m} \mathrm{a}^{-1}$ over the surveyed portion of the glacier. SB lost an average of only $0.32 \pm 0.02 \mathrm{~m} \mathrm{a}^{-1}$ despite high elevation losses at the terminus due to a significant portion of its area lying high on the Gruvfonna ice cap. Elevation changes across all sites averaged $-0.59 \pm 0.04 \mathrm{~m} \mathrm{a}^{-1}$ between 1961-2005. The frontal retreat and elevation losses we observe suggest that all six of our sites have likely undergone significant negative mass balance over the period of observation.

Pre- and post-1990 $\dot{\overline{\Delta h}}$ for each site are given in Table 4 and reveal a significant increase of thinning between these periods. Average $\dot{\overline{\Delta h}}$ accelerated from $-0.52 \pm 0.09 \mathrm{~m} \mathrm{a}^{-1}$ before 1990 to $-0.76 \pm 0.10 \mathrm{~m} \mathrm{a}^{-1}$ after 1990 representing a $46 \%$ increase in average thinning rate between the two periods. Increases in thinning rates over these periods of similar magnitude were previously reported on two of these glaciers in western Svalbard (Kohler et al., 2007). However, the inclusion of an intermediate epoch of photographs flown in 1977 at $\mathrm{AB}, \mathrm{ML}$ and $\mathrm{SB}$ illustrates the difficulty of interpreting elevation changes between two discrete points in time especially when separated by long periods. The rates of elevation change for $\mathrm{AB}, \mathrm{ML}$ and $\mathrm{SB}$ from Table 4 imply a uniform and significantly lower thinning rate before than after 1990. However, elevation changes for the intermediate period (1977-1990; Fig. 3) show how these change statistics can be misleading. At AB, the thinning rate in the first of the three periods is not significantly different from the most recent period; only the middle period has significantly lower thinning rates. This is not the case for ML where thinning rates in the first two periods are similar, whereas SB experienced a constant increase in thinning over all three periods.

Our analysis of these thinning rates by elevation reveals the most significant finding from the study: Some of the greatest increases in $\overline{\Delta h}$ occurred in the higher reaches of the glaciers in areas typical of snow accumulation and mass gain. As expected, elevation changes were greatest at lower altitudes with maximum changes reaching almost $-2.5 \mathrm{~m} \mathrm{a}^{-1}$ at SB (Fig. 4). However, plotting changes in $\dot{\overline{\Delta h}}$ against elevation for each site emphasises how the glaciers' upper reaches 

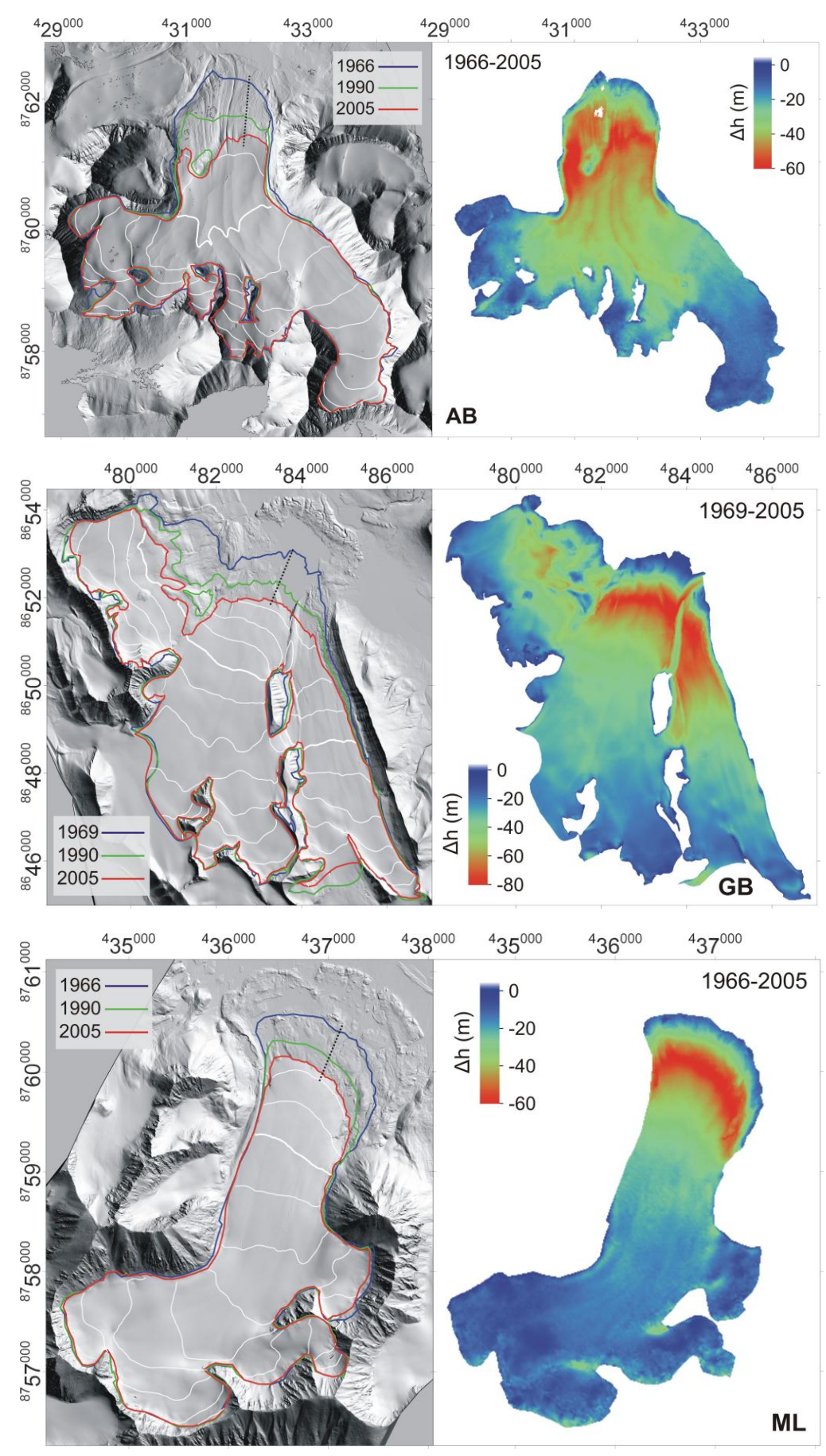

Fig. 2. Contemporary DEMs and sequential DEM analysis results (showing $\Delta h$ ) for: Austre Brøggerbreen (AB); Grønfjordbreen (GB); Midtre Lovénbreen (ML); Albrechtbreen (AL); Gullfaksebreen (GF); and Slakbreen (SB). Top and left-hand panels show the shaded-relief DEMs of 2005 lidar (2003 for SB) with elevations plotted on a $5 \mathrm{~m}$ grid and glacier outline overlays. Contour interval is $50 \mathrm{~m}$ with bold contour at $300 \mathrm{~m}$. Elevations in meters above sea level. Bottom and right-hand pannels show accompanying elevation change map on $10 \mathrm{~m}$ grid over the full period of data coverage. Plots for AL and GF show only the surveyed area of the glacier catchment (see Table 1).

at several sites are experiencing similar or indeed greater increases in thinning rates than at their termini (Fig. 5). Interestingly, an additional elevation change curve at ML from two lidar surveys in 2003 and 2005 shows the same pattern of enhanced thinning rates with elevation extending down to $200 \mathrm{~m}$ where only bare ice is found (Fig. 4). 

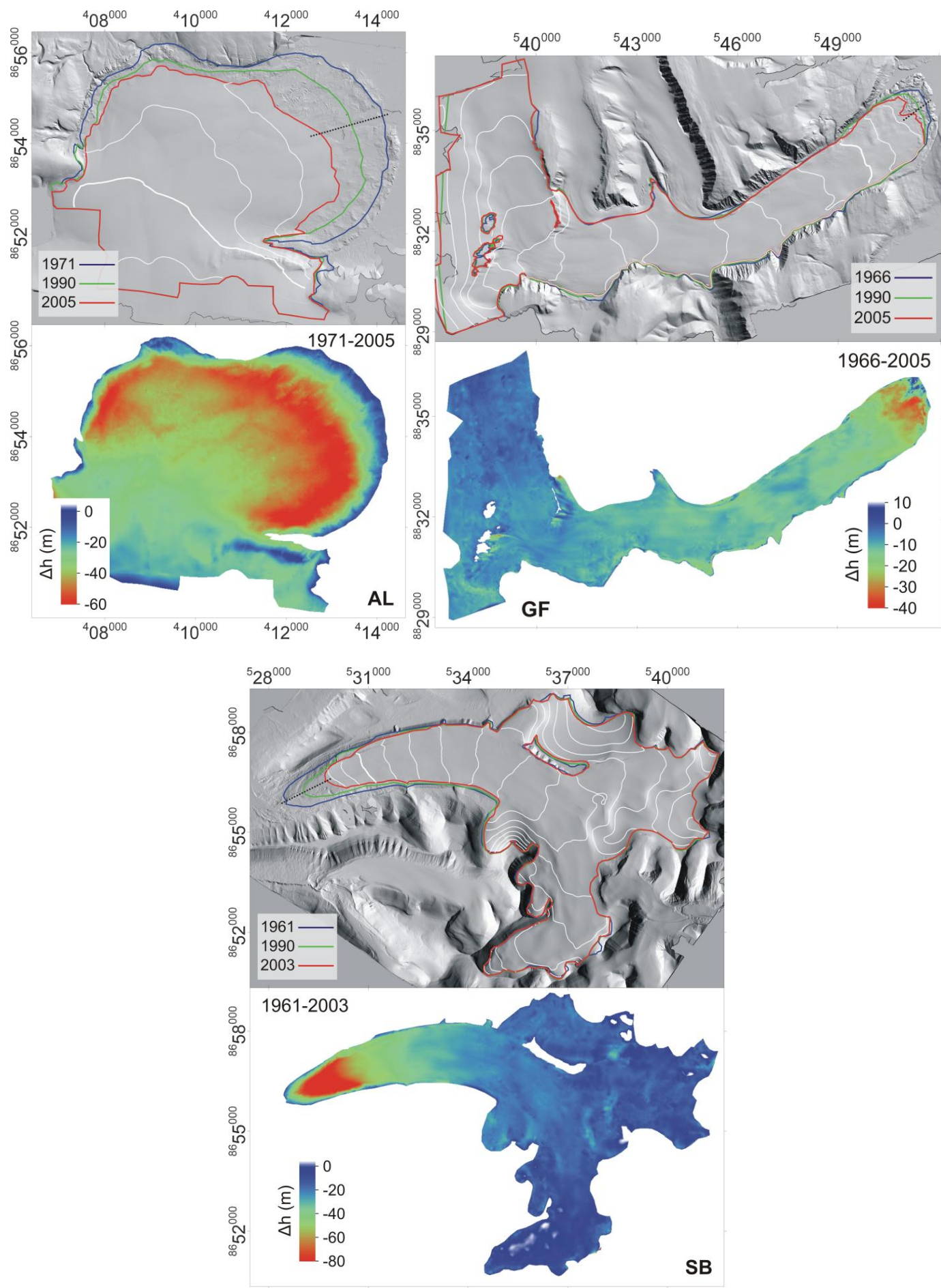

Fig. 2. Continued.

\section{Discussion}

Of the results presented in Fig. 1 and Tables 3 and 4, the most striking is the apparent high variability between sites, especially those located relatively close together. For example, of adjacent $\mathrm{AB}$ and $\mathrm{ML}$, the former thinned significantly more over the whole period than ML but at the same time experienced a smaller increase in thinning rates between the two epochs. Similarly, on average GB underwent twice the thinning of SB despite these glaciers being only $\sim 50 \mathrm{~km}$ apart and at similar latitude. However, looking at the elevation 


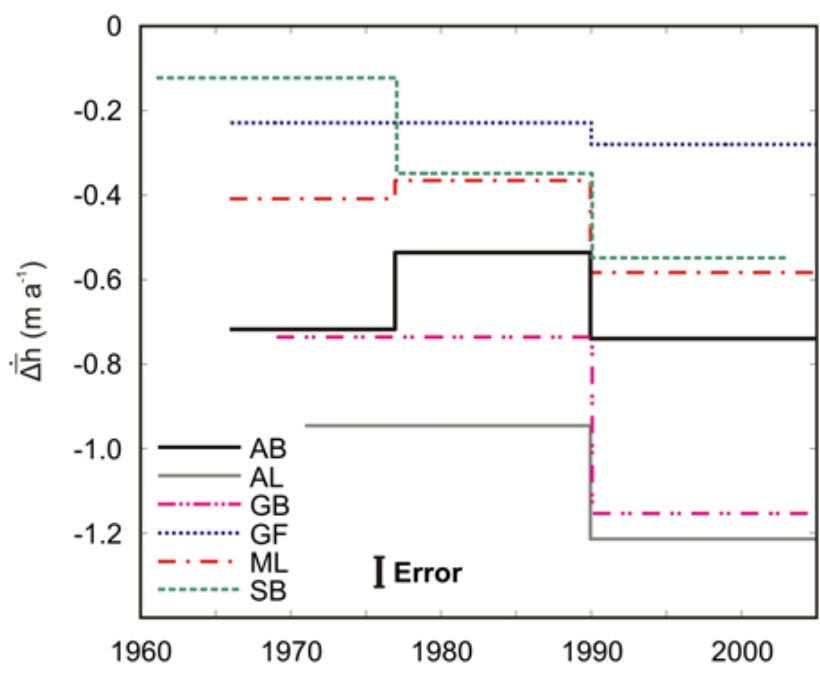

Fig. 3. Average annual elevation change $(\overline{\Delta h})$ over all periods including the intermediate epoch at $\mathrm{AB}, \mathrm{ML}$ and $\mathrm{SB}$.

change by altitude curves and site hypsometry (Fig. 4), particularly for $\mathrm{AB}$ and $\mathrm{ML}$ whose elevation changes by altitude are fairly similar, these differences are less surprising. Both ML and SB have a higher ice elevation distribution than their faster thinning neighbours. The large jump in thinning at ML between epochs can be explained by its greater ice area at elevations where higher increases in thinning rates were occurring. The comparatively small average elevation change at $\mathrm{SB}$, due to its large icecap between 700 and $800 \mathrm{~m}$, disguises the very high rates of thinning (up to $-2.4 \mathrm{~m} \mathrm{a}^{-1}$ between 1961 and 2003) that occurred at the glacier's terminus. In contrast, the difference in thinning rates between $A B$ and ML when taking the intermediate epoch into account does not appear to be attributable to hypsometric differences and must be due to some other yet unknown site-specific parameter.

For glaciers farther afield the effect of Svalbard's strong climatic gradients becomes apparent. GF experienced significantly lower mean thinning rates $\left(-0.25 \pm 0.03 \mathrm{~m} \mathrm{a}^{-1}\right)$ than at other sites despite our survey missing some of the catchment's higher elevations where thickening may be present. Nuth et al. (2010) found that the ice cap Åsgårdfonna, which is linked to GF, underwent average elevation changes of $-0.21 \pm 0.07 \mathrm{~m} \mathrm{a}^{-1}$ (after conversion from water equivalents) for the similar period, 1966-2007, which is within the margin of error of our measurement. On the other end of the spectrum, average changes at $\mathrm{AL}$ were highest of all our sites $\left(-1.00 \pm 0.03 \mathrm{~m} \mathrm{a}^{-1}\right)$. However, this glacier also had the lowest hypsometry and the highest third of the glacier's elevation range could not be included in the study. For the large but low-lying ice cap Edgeøyjøkulen, which contains the AL catchment, Nuth et al. (2010) measured average elevation changes of $-0.63 \pm 0.12 \mathrm{~m} \mathrm{a}^{-1}$ between 1966 and 2007 suggesting that our surveyed area is likely biased to- wards the more negative changes at the lower elevations of the catchment. The high frontal thinning rates measured at $\mathrm{AL}$ are similar to the $-2.0 \mathrm{~m} \mathrm{a}^{-1}$ measured by Kääb (2008) on the other Edgeøya ice caps.

A strong link between net mass balance and both summer temperatures and winter precipitation has been demonstrated in Svalbard (Hagen and Liestøl, 1990; Lefauconnier et al., 1999), and thus we interpreted our results in the context of the local meteorology. The high variability in thinning rates observed at our sites supports the regional approach used previously for archipelago-wide monitoring of Svalbard mass balance (i.e. Hagen et al., 2003b; Bamber et al., 2005; and Nuth et al., 2010). While it is tempting to consult data from all the meteorological stations around Svalbard to understand better the variation between sites, we argue the following: (i) the documented temperature and precipitation gradients in Svalbard, caused by its position between warm and cold oceanic and atmospheric currents (Rotschky et al., 2011), and the different local geometries, are sufficient to account for the observed variability; (ii) none of the stations in Svalbard are close enough to the sites to represent accurately local conditions; and (iii) temperature (and to a lesser extent precipitation) at Longyearbyen is correlated with other stations in Svalbard (Førland and Hanssen-Bauer, 2003) and only the Longyearbyen record covers our study period. Therefore, we base the following discussion on data from the Longyearbyen (Svalbard airport) meteorological station (L, Fig. 1).

Between 1961 and 2005, annual mean temperature at Longyearbyen increased by $1.8^{\circ} \mathrm{C}$. However, high interannual and decadal variability means long-term trends must be large in order to be statistically significant (Førland and Hanssen-Bauer, 2003). Alternatively, the June, July, August (JJA) mean temperature at Longyearbyen increased significantly (with $95 \%$ confidence) by $0.02{ }^{\circ} \mathrm{Ca}^{-1}$ between $1961-$ 2005 (Fig. 6). No significant trend was measured during 1961-1990, but JJA temperatures after 1990 increased significantly by $0.07^{\circ} \mathrm{Ca}^{-1}$. These warming temperature trends are likely driving the acceleration of thinning at low elevations.

To investigate the intermediate period of lower thinning rates, we calculated the average annual sum of positive degree days (PDD) from the Longyearbyen mean daily temperature record for each period and compared them to the mean PDD for the whole time series (Fig. 6). This comparison revealed that the 1980s were indeed a period of significantly cooler summer temperatures at Longyearbyen than either the preceding or following period. While this accounts for the mass loss at $\mathrm{AB}$ and ML during this period, this appears not to have occurred further south at SB where there is no evidence of glacier response to this cooler period. This is indicative of the extreme regionality of Svalbard's climate and the strong sensitivity of glaciers to even decadal meteorological trends. Coincidentally, the Svalbard mass balance research published in the 1990s (Hagen and Liestøl, 1990; Dowdeswell et al., 1997; Lefauconnier et al., 1999) 


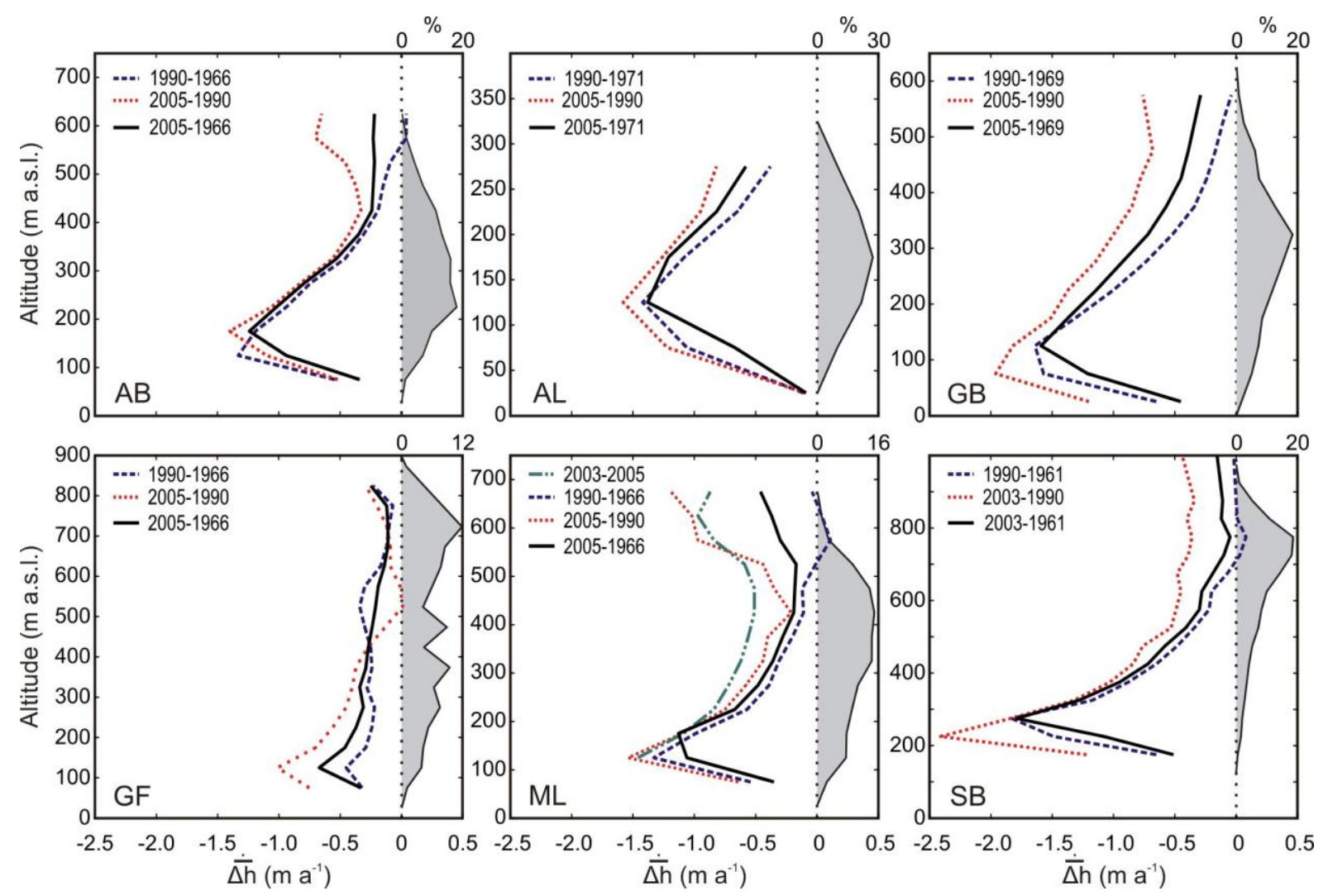

Fig. 4. Elevation change curves for the six survey sites, shown in $50 \mathrm{~m}$ altitude bins (bottom axis). Decreased thinning rates at lowest elevations reflect the thinning of the front to zero ice thickness between epochs and thus terminus retreat. Right side of each panel provides relative hypsometry of each site in percentage of total area (top axis; see Table 3).

Table 3. Glacier elevation and volume change statistics derived from DEM differencing over the full period of data coverage. Mean area $(\bar{A})$; maximum total elevation change $\left(\Delta h_{\max }\right)$; mean elevation change $(\overline{\Delta h})$; mean annual elevation change $(\dot{\overline{\Delta h}})$; total volume change $(\Delta V)$; and total annual volume change $(\Delta \vec{V})$.

\begin{tabular}{lcrrcccc}
\hline Site & $\begin{array}{c}\text { Study } \\
\text { Period }\end{array}$ & $\begin{array}{r}\bar{A} \\
\left(\mathrm{~km}^{2}\right)\end{array}$ & $\begin{array}{r}\Delta h_{\max } \\
(\mathrm{m})\end{array}$ & $\begin{array}{c}\overline{\Delta h} \\
(\mathrm{~m})\end{array}$ & $\begin{array}{c}\dot{\Delta} \\
\left(\mathrm{m} \mathrm{a}^{-1}\right)\end{array}$ & $\begin{array}{c}\Delta V \\
\left(\times 10^{5} \mathrm{~m}^{3}\right)\end{array}$ & $\begin{array}{c}\Delta V \\
\left(\times 10^{4} \mathrm{~m}^{3} \mathrm{a}^{-1}\right)\end{array}$ \\
\hline AB & $1966-2005$ & $10.96 \pm 0.04$ & $-67 \pm 1$ & $-25 \pm 1$ & $-0.64 \pm 0.03$ & $-2.73 \pm 0.11$ & $-0.70 \pm 0.03$ \\
AL & $1971-2005$ & $28.56 \pm 0.09$ & $-73 \pm 1$ & $-34 \pm 1$ & $-1.00 \pm 0.03$ & $-9.71 \pm 0.29$ & $-2.86 \pm 0.09$ \\
GB & $1969-2005$ & $35.83 \pm 0.12$ & $-94 \pm 1$ & $-31 \pm 1$ & $-0.87 \pm 0.03$ & $-11.3 \pm 0.37$ & $-3.13 \pm 0.10$ \\
GF* & $1966-2005$ & $42.98 \pm 0.14$ & $-38 \pm 1$ & $-10 \pm 1$ & $-0.25 \pm 0.03$ & $-4.17 \pm 0.44$ & $-1.07 \pm 0.11$ \\
ML & $1966-2005$ & $5.47 \pm 0.02$ & $-66 \pm 1$ & $-17 \pm 1$ & $-0.44 \pm 0.03$ & $-0.94 \pm 0.06$ & $-0.24 \pm 0.01$ \\
SB & $1961-2003$ & $40.18 \pm 0.13$ & $-102 \pm 1$ & $-13 \pm 1$ & $-0.32 \pm 0.02$ & $-5.34 \pm 0.41$ & $-1.27 \pm 0.10$ \\
\hline
\end{tabular}

* Note the AL and GF catchments were not completely surveyed (see Table 1).

was based on time series that terminated around the end of this cold period, which would explain the lack of trend in rates of mass loss for many of these earlier studies. There is clearly a need to interpret geodetic volume and mass changes in the context of the prevailing meteorological conditions at the time of each epoch in the time series.

We also performed an analysis of Longyearbyen precipitation data. Due to the strong precipitation gradients in
Svalbard, the Longyearbyen station is likely only representative of the west coast (Hanssen-Bauer, 2002). However, this is the only station that extends back to the beginning of our time series. Additionally, it is important to note that precipitation measurements are notoriously prone to error, especially in Arctic conditions and, without sitespecific correction factors, should be interpreted with caution (Førland and Hanssen-Bauer, 2000). These data revealed 
Table 4. Mean annual elevation change rates $(\dot{\overline{\Delta h}})$ for pre-1990, post-1990 and whole period of data coverage.

\begin{tabular}{llccc}
\hline & & \multicolumn{3}{c}{$\dot{\overline{\Delta h}}\left(\mathrm{~m} \mathrm{a}^{-1}\right)$} \\
\cline { 3 - 5 } & & Whole Period & Pre-1990 & Post-1990 \\
\hline AB & $1966-2005$ & $-0.64 \pm 0.03$ & $-0.62 \pm 0.09$ & $-0.74 \pm 0.10$ \\
AL* & $1971-2005$ & $-1.00 \pm 0.03$ & $-0.95 \pm 0.11$ & $-1.21 \pm 0.10$ \\
GB & $1969-2005$ & $-0.87 \pm 0.03$ & $-0.74 \pm 0.10$ & $-1.15 \pm 0.10$ \\
GF* & $1966-2005$ & $-0.25 \pm 0.03$ & $-0.22 \pm 0.09$ & $-0.28 \pm 0.10$ \\
ML & $1966-2005$ & $-0.44 \pm 0.03$ & $-0.38 \pm 0.09$ & $-0.58 \pm 0.10$ \\
SB & $1961-2003$ & $-0.32 \pm 0.03$ & $-0.22 \pm 0.07$ & $-0.55 \pm 0.12$ \\
\hline
\end{tabular}

* Note the AL and GF catchments were not completely surveyed (see Table 1).

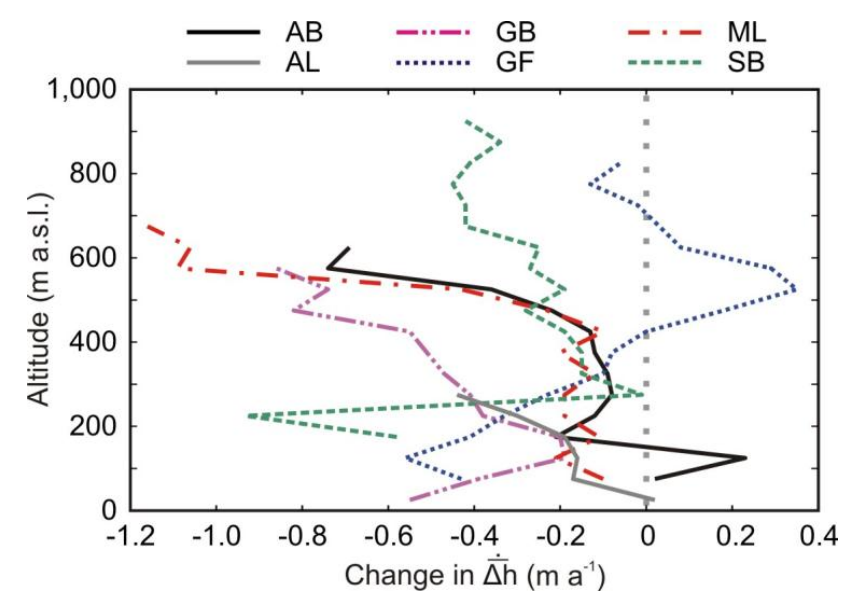

Fig. 5. Differencing elevation change rates from pre-1990 and post1990 periods by altitude highlights the speedup in thinning is greatest at higher elevations with only GF in the far NE as the exception.

a strong post-1990 negative trend in total precipitation of $4.4 \mathrm{~mm} \mathrm{a}^{-1}$ (significant at $95 \%$ confidence; standard error, $2.2 \mathrm{~mm}$ ) but no significant trend over the whole period. In contrast, solid precipitation decreased significantly since $1961\left(-0.9 \mathrm{~mm} \mathrm{a}^{-1}\right.$; standard error, $\left.0.2 \mathrm{~mm}\right)$ with a stronger negative trend since $1990\left(-3.0 \mathrm{~mm} \mathrm{a}^{-1}\right.$; standard error, $1.4 \mathrm{~mm}$ ). To put the precipitation decreases into context, at these rates annual precipitation in 2005 was predicted to be $\sim 45 \mathrm{~mm}$ less than it was in 1990 in a region with already relatively low accumulation rates of less than $1 \mathrm{~m}$ w.e. $\mathrm{a}^{-1}$ (Hagen et al., 2003a). This reduction in accumulation could in several ways account for the increases in thinning rates we have observed in the glaciers' upper reaches. First, such a loss of snow cover would decrease internal accumulation in these higher areas and potentially cause a redistribution of superimposed ice to lower elevations (e.g. Zwinger and Moore, 2009). At ML and likely elsewhere in Svalbard, superimposed ice is known to be a significant component of mass balance (Wright et al., 2007) and this could be responsible for a non-linear ablation gradient. Second, there could be a dynamic component to these changes since it is likely

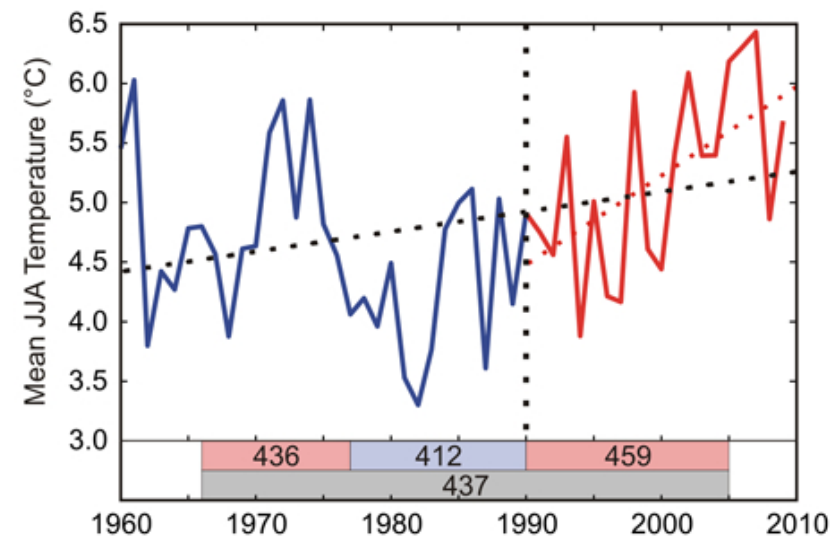

Fig. 6. JJA Temperature data from the Longyearbyen station (L, Fig. 1). Trend for whole period (black dotted line) is $0.02{ }^{\circ} \mathrm{Ca}^{-1}$ whereas the trend for the post- 1990 period was $0.07^{\circ} \mathrm{Ca}^{-1}$ (at $95 \%$ confidence). No significant trend was measured for the pre- 1990 period. Average PDDs for each period and for the whole study period at Longyearbyen meteorological station (L, Fig. 1) are given at the bottom of the main panel.

that the submergence velocities are not in balance with the decreasing trend in mass input in the accumulation areas. Finally, in areas with a significant firn layer, elevation changes could have resulted from firm compaction. However, it is important to note that the elevation change by altitude curve for ML between 2003 and 2005 (Fig. 4) highlights that enhanced thinning occurs far down the glacier in areas where only bare ice was measured in these two years.

Changes in surface albedo are also linked to decreasing trends in winter precipitation and could explain the greater increases in thinning rates at higher elevations. Research has demonstrated the significant effect a decrease in glacier albedo due to loss of snow cover has on enhancing ablation (Oerlemans et al., 2009), and such changes were identified as a major contributing factor in the large 2010 negative surface mass balance anomaly of the Greenland Ice Sheet (Tedesco et al., 2011). In Svalbard, Kohler et al. (2007) hypothesized that indications of higher elevation thinning at two of these sites might be explained by a decrease in albedo due to loss of snow cover, and our observations are consistent with this hypothesis. However, it is also possible that a localised decrease in albedo could result from increased dust accumulation on snow and ice surfaces as a result of the exposure of new bedrock in areas of steep headwalls. In the imagery and during flyovers, we observed substantial quantities of dust on the snow surface at GB and SB, which are near active coal mines, but not at the other sites. While studies measuring temporal/spatial changes in glacier albedo (Greuell et al., 2007) and snow cover/melt (Rotschky et al., 2011) on a widescale have been undertaken using satellite-derived data, the short time scale and spatial resolution of available data are not suitable for resolving the changes we observe. 
This newly exposed bedrock in the headwall area could also locally influence the radiation budget at these higher elevations, though these areas are relatively small. Without local data on snow cover, changes in albedo and local energy budgets at our sites over the period of study, the cause of these changes remains uncertain.

Independent of their cause, the changes we have observed if widespread will have important implications on the mass balance of the archipelago. Critically, Svalbard's ice is especially sensitive to changes in the equilibrium line altitude (ELA) due to its hypsometric distribution which places the bulk of Svalbard's ice close to the current estimated ELA. Consequently, even small changes in the ELA will have a large impact on the mass balance of the archipelago (Hagen et al., 2003b). To illustrate, at its estimated average altitude of $\sim 460 \mathrm{~m}$ a.s.l. and accumulation area ratio (AAR) of 0.44 (calculated from our hypsometry data), a $50 \mathrm{~m}$ increase in the ELA (or an equivalent surface lowering) would result in a loss of $\sim 3000 \mathrm{~km}^{2}$ of accumulation area and a new AAR of 0.36 - equal to $\sim 8 \%$ of Svalbard's ice-covered area and $\sim 18 \%$ of the accumulation zone according to most recent estimates (Hagen et al., 1993). However, these hypsometry and ELA estimates are based largely on the 1990 aerial survey and our results show that significant changes have taken place since the 1990 survey was undertaken. This is demonstrated by the total area-altitude distribution for our sites during the early 1990 and 2003/5 epochs (Fig. 7) showing how the ice area has lowered over this $44-y r$ period.

\section{Conclusions}

Our high-resolution time series of glacier DEMs derived from archived aerial photographs and lidar reveal high variability in elevation changes and retreat rates between our sites. This is indicative of the strong regionality of Svalbard's climate and highlights the difficulty of using a small number of index glaciers to represent changes of a region. However, despite this variability there is a prevalent increase in thinning at all sites between the periods 1961-1990 and 19902005. Of particular note is an increase in thinning rates in the glaciers' upper reaches of similar magnitude to that measured at the glaciers' termini. We find that these changes are coincident with increasing trends in summer temperatures and decreasing trends in winter precipitation. While their cause is not yet clear, we suggest that the loss of snow cover could be altering the albedo of these higher regions, causing changes to the distribution of superimposed ice and/or creating an imbalance between mass input and submergence velocities. Clearly, more research is needed to determine the causes and extent of these changes.

Regardless of their cause, these high elevation changes, if widespread, could act to raise the ELA and decrease the AAR in an area whose mass balance is known to be highly sensitivity to such changes (Hagen et al., 2003b). However,

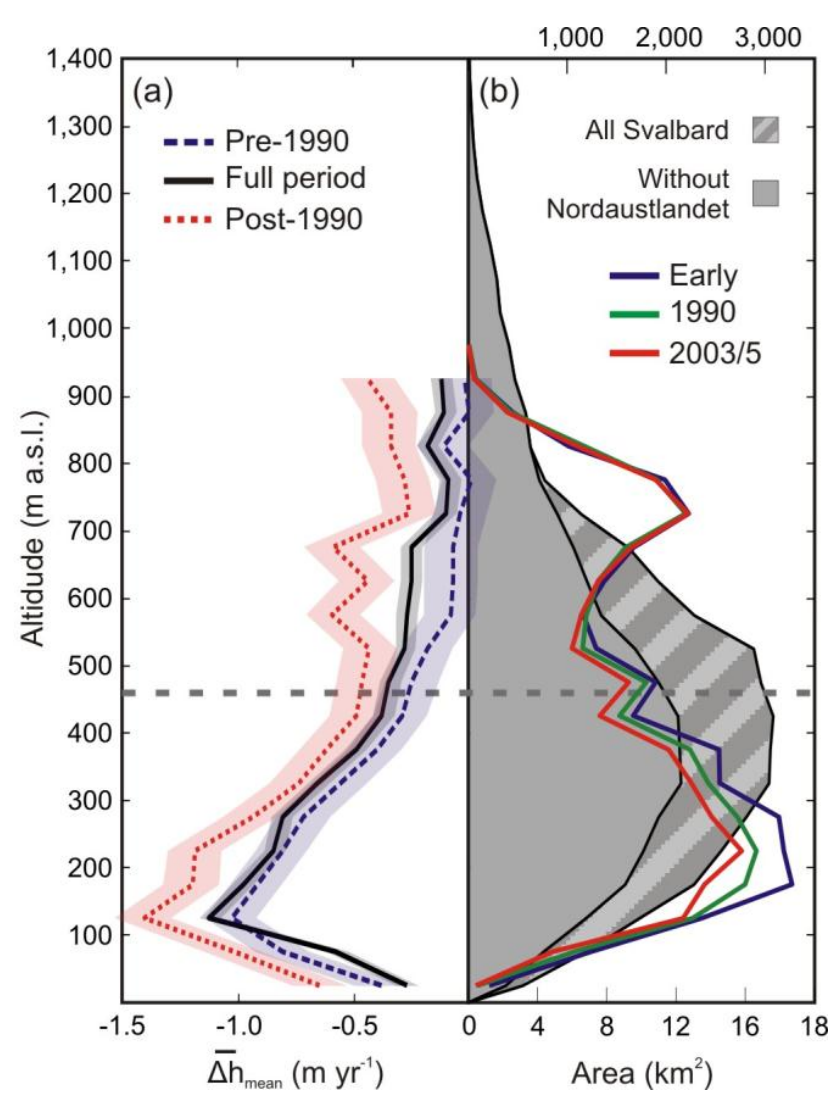

Fig. 7. Hypsometric context of elevation changes at our sites. (a) Elevation change with altitude is plotted to show annual changes before and after 1990 and over the whole period of data coverage. Error estimates are represented by the shading around each curve. The horizontal dashed line is the estimated average ELA of $\sim 460 \mathrm{~m}$ a.s.l. from Hagen et al. (2003b); (b) Total hypsometry of the study sites for early 1990 and 2003/5 epochs (bottom axis) overlying the hypsometry of Svalbard (top axis) inclusive and exclusive of the ice of Nordaustlandet and Kvitøya all calculated in $50 \mathrm{~m}$ elevation bands.

we have found that when measuring geodetic elevation and mass changes, the timing of photographic epochs within the decadal climate variability can have a significant impact on implied changes over the period. We advise caution when interpreting such results in the absence of reliable local climate data, especially in regions with strong climate gradients like Svalbard. Our findings highlight a need for continued highresolution monitoring of Svalbard glaciers.

Acknowledgements. SLICES was funded by the UK NERC (NE/B505203/1). TDJ's work was also supported by the GLIMPSE project funded by The Leverhulme Trust (F/00391/J) and the Climate Change Consortium for Wales (C3W). NEB's contribution was supported by NERC studentship NER/S/A/2003/11279. Lidar data were flown by the NERC Airborne Research and Survey Facility and processed by the Unit for Landscape Modelling, University of Cambridge. Access and facilities at the Ny-Ålesund 
geodetic observatory were provided by Statens Kartverk, Norway. The authors would like to thank: BAE Systems (SOCETSET), Applied Imagery (Quick Terrain Modeler) and Jack Kohler (Norwegian Polar Institute) for their support. Field assistants included Artur Adamek, Trine Abrahamsen, Brian Barrett, Suzanne Bevan, Remko de Lange, Adrian Luckman and Irina Solovjanova. Finally, we would like to thank three anonymous reviewers, M. Pelto and the editor for their constructive comments which helped to improve significantly this manuscript.

Edited by: A. Kääb

\section{References}

Bamber, J. L., Krabill, W., Raper, V., Dowdeswell, J. A., and Oerlemans, J.: Elevation changes measured on Svalbard glaciers and ice caps from airborne laser data, Ann. Glaciol., 42, 202-208, 2005.

Barrand, N. E., Murray, T., James, T. D., Barr, S. L., and Mills, J. P.: Optimizing photogrammetric DEMs for glacier volume change assessment using laser-scanning derived ground-control points, J. Glaciol., 55, 106-116, 2009.

Barrand, N. E., James, T. D., and Murray, T.: Spatio-temporal variability in elevation changes of two high-Arctic valley glaciers, J. Glaciol., 56, 771-780, 2010.

Berthier, E., Schiefer, E., Clarke, G. K. C., Menounos, B., and Rémy, F.: Contribution of Alaskan glaciers to sea-level rise derived from satellite imagery, Nat. Geosci., 3, 92-95, doi:10.1038/NGEO737, 2010.

Chen, G.: GPS Kinematic Positioning for the Airborne Laser Altimetry at Long Valley, California, Ph.D. thesis, Massachusetts Institute of Technology, Cambridge, 179 pp., 1998.

Cox, L. H. and March, R. S.: Comparison of geodetic and glaciological mass-balance techniques, Gulkana Glacier, Alaska, U.S.A., J. Glaciol., 50, 363-370, 2004.

Dowdeswell, J. A., Hagen, J. O., Björnsson, H., Glazovsky, A. F., Harrison, W. D., Holmlund, P., Jania, J., Koerner, R. M., Lefauconnier, B., Ommanney, C. S. L., and Thomas, R. H.: The mass balance of circum-Arctic glaciers and recent climate change, Quaternary Res., 48, 1-14, 1997.

Etzelmüller, B., Vatne, G., Odegard, R. S., and Sollid, J. L.: Massbalance and changes of surface slope, crevasse and flow pattern of Erikbreen, Northern Spitsbergen - an application of a geographical information system (GIS), Polar Res., 12, 131-146, 1993.

Fleming, K. M., Dowdeswell, J. A., and Oerlemans, J.: Modelling the mass balance of northwest Spitsbergen glaciers and responses to climate change, Ann. Glaciol., 24, 203-210, 1997.

Førland, E. J. and Hanssen-Bauer, I.: Increased precipitation in the Norwegian Arctic: True or False?, Climate Change, 46, 485-509, 2000.

Førland, E. J. and Hanssen-Bauer, I.: Past and future climate variations in the Norwegian Arctic: overview and novel analyses, Polar Res., 22, 113-124, 2003.

Greuell, W., Kohler, J., Obleitner, F., Glowacki, P., Melvold, K., Bernsen, E., and Oerlemans, J.: Assessment of interannual variations in the surface mass balance of 18 Svalbard glaciers from the Moderate Resolution Imaging Spectrora-
diometer/Terra albedo product, J. Geophys. Res., 112, D07105, doi:10.1029/2006JD007245, 2007.

Hagen, J. O. and Liestøl, O.: Long-term glacier mass balance investigations in Svalbard, 1950-88, Ann. Glaciol., 14, 102-106, 1990.

Hagen, J. O., Liestøl, O., Roland, E., and Jørgensen, T.: Glacier atlas of Svalbard and Jan Mayen, Norsk Polarinstitutt, Oslo, 141 pp., 1993.

Hagen, J. O., Kohler, J., Melvold, K., and Winther, J. G.: Glaciers in Svalbard: mass balance, runoff and freshwater flux, Polar Res., 22, 145-159, 2003a.

Hagen, J. O., Melvold, K., Pinglot, F., and Dowdeswell, J. A.: On the net mass balance of the glaicers and ice caps in Svalbard, Norwegian Arctic, Arct. Antarct. Alp. Res., 35, 264-270, 2003 b.

Hanssen-Bauer, I.: Temperature and precipitation in Svalbard 19122050: measurements and scenarios, Polar Rec., 38, 225-232, 2002.

Herring, T. A., King, R. W., and McClusky, S. C.: Documentation for the GAMIT GPS analysis software, version 10.40 Rep., Massachusetts Institute of Technology, Cambridge, 2010.

James, T. D., Murray, T., Barrand, N. E., and Barr, S. L.: Extracting photogrammetric ground control from lidar DEMs for change detection, Photogramm. Rec., 21, 310-326, 2006.

Joerg, P. C., Morsdorf, F., and Zemp, M.: Uncertainty assessment of multi-temporal airborne laser scanning data: a case study on an alpine glacier, Remote Sens. Environ., 127, 118-129, 2012.

Kääb, A.: Glacier volume changes using ASTER satellite stereo and ICESat GLAS laser altimetry. A test study on Edgeoya, Eastern Svalbard, IEEE T. Geosci. Remote Sens., 46, 2823-2830, doi:10.1109/TGRS.2008.2000627, 2008.

Kohler, J., James, T. D., Murray, T., Nuth, C., Brandt, O., Barrand, N. E., Aas, H. F., and Luckman, A. J.: Acceleration in thinning rate on western Svalbard glaciers, Geophys. Res. Lett., 34, L18502, doi:10.1029/2007GL030681, 2007.

Lefauconnier, B., Hagen, J. O., Ørbæk, J. B., Melvold, K., and Isaksson, E.: Glacier balance trends in the Kongsfjorden area, western Spitsbergen, Svalbard, in relation to climate, Polar Res., 18, 307-313, 1999.

Moholdt, G., Nuth, C., Hagen, J. O., and Kohler, J.: Recent elevation changes of Svalbard glaciers derived from ICESat laser altimetry, Remote Sens. Environ., 114, 2756-2767, 2010.

Nuth, C., Kohler, J., Aas, H. F., Brandt, O., and Hagen, J. O.: Glacier geometry and elevation changes on Svalbard (1936-90): a baseline dataset, Ann. Glaciol., 46, 106-116, 2007.

Nuth, C., Moholdt, G., Kohler, J., Hagen, J. O., and Kääb, A.: Svalbard glacier elevation changes and contribution to sea level rise, J. Geophys. Res.-Earth, 115, F01008, doi:10.1029/2008JF001223, 2010.

Oerlemans, J., Giesen, R. H., and van den Broeke, M. R.: Retreating alpine glaciers: increased melt rates due to accumulation of dust (Vadret da Morteratsch, Switzerland), J. Glaciol., 55, 729-736, 2009.

Rolstad, C., Haug, T., and Demby, B.: Spatially integrated geodetic glacier mass balance and its uncertainty based on geostatistical analysis: application to the western Svartisen ice cap, Norway, J. Glaciol., 55, 666-680, 2009.

Rotschky, G., Schuler, T. V., Haarpaintner, J., Kohler, J., and Isaksson, E.: Spatio-temporal variability of snowmelt across Svalbard during the period 2000-08 derived from 
QuickSCAT/SeaWinds scatterometry, Polar Res., 30, 5963, doi:10.3402/polar.v30i0.5963, 2011.

Schwitter, M. P. and Raymond, C. F.: Changes in the longitudinal profiles of glaciers during advance and retreat, J. Glaciol., 39, 582-590, 1993.

Tedesco, M., Fettweis, X., van den Broeke, M. R., Van de Wal, R. S. W., Smeets, C. J. P. P., van de Berg, W. J., Serreze, M. C., and Box, J. E.: The role of albedo and accumulation in the 2010 melting record in Greenland, Environ. Res. Lett., 6, 014005 , doi:10.1088/1748-9326/6/1/014005, 2011.

Wehr, A. and Lohr, U.: Airborne laser scanning - an introduction and overview, ISPRS J. Photogramm., 54, 68-82, 1999.
Wolf, P. R. and Dewitt, B. A.: Elements of Photogrammetry, with Applications in GIS, 3rd Edn., McGraw-Hill, New York, 608 pp., 2000.

Wright, A. P., Wadham, J. L., Siegert, M. J., Luckman, A., Kohler, J., and Nuttall, A. M.: Modeling the refreezing of meltwater as superimposed ice on a high Arctic glacier: A comparison of approaches, J. Geophys. Res., 112, F04016, doi:10.1029/2007JF000818, 2007.

Zwinger, T. and Moore, J. C.: Diagnostic and prognostic simulations with a full Stokes model accounting for superimposed ice of Midtre Lovénbreen, Svalbard, The Cryosphere, 3, 217-229, doi:10.5194/tc-3-217-2009, 2009. 